\title{
Além do Estado e da ideologia: imigração judaica, Estado-Novo e Segunda Guerra Mundial
}

Roney Cytrynowicz

Doutor História-USP

\section{RESUMO}

A partir de uma pesquisa em fontes primárias das instituições centrais associadas à imigração judaica em São Paulo e Rio de Janeiro, este artigo mostra como, durante o Estado-Novo e a Segunda Guerra Mundial, as entidades judaicas funcionaram de forma corriqueira, adaptaram-se às restrições nacionalistas do governo Getúlio Vargas e, muitas vezes, engendraram estratégias sofisticadas para enfrentar a lei e a ideologia. Esta perspectiva de história social e do cotidiano evidencia, portanto, uma leitura distinta daquela que - analisando exclusivamente a lei, a ideologia e o preconceito do regime Vargas - considera que havia um clima de medo e perseguição generalizado entre os imigrantes judeus residentes no País. Este artigo mostra, complementarmente, que 1937-1945 foram anos decisivos para a implantação de uma comunidade etnicamente ativa e para a sedimentação de uma identidade judaico-brasileira.

Palavras-chave: Estado-Novo; imigração judaica; Segunda Guerra Mundial.

\section{ABSTRACT}

This article shows that, during the Estado Novo and World War II, Jewish institutions adapted themselves to Vargas and nationalist restrictions, and created sophisticated strategies to undermine both law and national ideology. This social history perspective, based on primary documents from major institutions associated with Jewish immigrants in Sao Paulo and Rio de Janeiro, provides an important corrective to the historiography that focuses on law, elite ideology and prejudice during the Vargas regime, giving the erroneous impression that Jews lived in a climate of fear and generalized persecution in Brazil. This article also shows that the years 1937- 1945 were decisive in for formation of an ethnically active community that created a clear Jewish-Brazilian identity.

Keywords: Estado Novo; Jewish immigration; World War II. 
Do ponto de vista da história contemporânea do Brasil e da história dos judeus no Brasil, o período do Estado Novo, entre 1937 e 1945, e mais especificamente o período da Segunda Guerra Mundial, têm sido abordados predominantemente por interpretações que enfatizam o anti-semitismo e colocam o preconceito e a perseguição como a marca dominante da vida dos imigrantes naquele período. Esta interpretação, tanto da historiografia como da memória social do próprio grupo, tende a considerar a comunidade judaica no Brasil entre 1937 e 1945 como um grupo acuado e ameaçado. No mesmo diapasão, esta interpretação tende a ver o Estado Novo e a ditadura de Getúlio Vargas como um regime próximo à Alemanha nazista, na ideologia e nas ações políticas ${ }^{1}$.

Este artigo pretende mostrar como a perspectiva de olhar a história dos imigrantes judeus no Brasil como uma história exclusivamente de anti-semitismo é parcial e limitada, e como pode ser equivocada se a tomarmos como único prisma para estudar o período $1937-1945^{2}$. A história do preconceito naquele período permite conhecer muito pouco sobre a história dos imigrantes no Brasil (após superar as barreiras legais e políticas para a sua entrada). O preconceito diz respeito à história da política e da ideologia do regime de Getúlio Vargas e das políticas imigratórias, além, é claro, da história do antisemitismo, dos regimes ditatoriais no período e da história dos refugiados da Europa tentando encontrar algum porto seguro.

Pode-se dizer que existe atualmente uma barreira ideológica na historiografia brasileira e na historiografia sobre imigração, e igualmente na memória oficial das instituições judaicas no Brasil: a formulação genérica e indiscriminada de que os imigrantes judeus, que estavam dentro do Brasil, viveram acuados e foram perseguidos enquanto grupo entre 1937 e 1945. Esta interpretação tem seguindo uma tendência na historiografia e nas ciências sociais brasileiras de compreender a história predominantemente a partir da ação do Estado, de suas leis e de sua ideologia, o que é insuficiente na perspectiva da história social. No caso do governo Vargas e do Estado-Novo, este paradigma tem se manifestado cada vez mais parcial. O estudo da imigração, do cotidiano e da cultura popular propicia uma visão diferente da que se tem quando se estuda o caráter do Estado e de sua ideologia. Embora o discurso oficial entre 1937 e 1945 fosse próximo ao fascismo, a sociedade não acompanhou esta direção, a cultura oficial não suplantou a cultura popular e a mobilização patriótica não arregimentou a população, nem mesmo durante a guerra.

Pode-se afirmar, como se verá ao longo deste artigo, que entre 1937 e 1945 as comunidades judaicas de São Paulo e do Rio de Janeiro viveram uma intensa e pública vida institucional, social, cultural e econômica. Foram anos de efervescência institucional que permitiram um boom de atividades e organizações, inclusive sionistas e comunistas, logo após 1945. Foram anos de se- 
dimentação institucional e de definição de uma identidade "judaico-brasileira”. A comunidade de São Paulo, com cerca de 56 mil membros em 1940, ocupou-se de auxiliar os refugiados durante a guerra, mas esta foi apenas uma pequena parcela de suas preocupações. Apesar das restrições legais impostas pelo Estado Novo de falar em público, de ensinar e de publicar em línguas consideradas "estrangeiras", da ação da polícia política, e apesar de um processo de "nacionalização", legal e ideológico, que forçou a mudança de diretoria e de nome de várias entidades dos grupos considerados "estrangeiros" (especialmente de imigrantes e nacionais italianos, alemães e japoneses), as instituições judaicas trabalharam serenamente para adequar-se às restrições e funcionaram ativamente durante o período.

Enquanto grupo, os judeus não sofreram nenhuma perseguição específica, sendo submetidos aos mesmos constrangimentos e proibições que outros grupos imigrantes, de falar, ensinar ou editar jornais em línguas consideradas "estrangeiras". Tampouco foram excetuados, no caso dos judeus-alemães, quando o governo brasileiro impôs restrições aos nacionais alemães no Brasil como inimigos do Eixo. É fundamental ressaltar que o argumento deste artigo refere-se exclusivamente aos imigrantes judeus, que constituíram uma parcela muito pequena do total de imigrantes chegados ao País a partir no último quartel do século 19. No caso dos imigrantes japoneses, a partir de 1937 a repressão foi mais dirigida e intensa e culminou, na cidade de São Paulo, com a expulsão de centenas de pessoas de suas casas na região central da cidade; igualmente distinto é o caso dos imigrantes alemães no sul do País.

Além de adaptar-se às imposições, as instituições judaicas urdiram estratégias sutis e sofisticadas para enfrentar as restrições do Estado Novo e as medidas de nacionalização. As entidades enfrentaram as restrições impostas pelo Estado Novo e o clima de intimidação geral imposto pela polícia política, especialmente a partir de 1942, quando o Brasil declarou guerra ao Eixo. A leitura das atas de uma ampla gama de instituições judaicas, assistenciais, escolas, sinagogas, entidades culturais, permite conhecer o que ocorreu internamente a estas instituições e como elas reagiram às restrições do Estado Novo.

Este artigo segue a linha interpretativa do historiador Jeffrey Lesser que, em sua obra sobre imigração, enfatiza as estratégias engendradas pelos diferentes grupos étnicos e mostra como, mesmo em situações adversas e mesmo diante de restrições do Estado, os grupos organizam diferentes respostas, que podem ser entendidas como diferentes estratégias de identidade. Esta perspectiva deve ser considerada para que os grupos minoritários não sejam considerados apenas vítimas passivas do Estado ou da ideologia oficial, ou tendo uma atitude apenas de reação diante do discurso dominante - o que lhes retira a condição de sujeito ${ }^{3}$. Como mostrou Lesser em seu estudo sobre imigração judaica, e depois sírio-libanesa e japonesa, é possível reconhecer pa- 
drões de estratégias para lidar com o discurso da maioria e estas estratégias podem ser ativas e etnicamente afirmativas. Seu estudo permite uma nova forma de entender a identidade e sua negociação entre os grupos, a sociedade e o Estado, cujo discurso e ações nem sempre são o único fator determinante. Neste sentido, o conceito de identidade não é considerado uma essência imutável que apenas responde a partir de um núcleo invariante, mas como um processo de permanente negociação (sempre em diálogo uma tradição ou com um ponto de referência fixo) entre o grupo e o entorno, ou como permanente reelaboração e diálogo em torno de um núcleo que se pode chamar de tradição $0^{4}$.

O anti-semitismo esteve presente nos anos 1930 e 1940 em importantes círculos do governo, especialmente o Itamaraty, e sua mais grave conseqüência foram as circulares secretas que restringiram a imigração de judeus ao Brasil a partir de 1937. Este anti-semitismo produziu episódios terríveis, como a história dos três mil vistos a católicos não-arianos que o Vaticano solicitou ao governo brasileiro e que, em sua maior parte, acabaram sendo recusados, conforme o livro do historiador Avraham Milgram ${ }^{5}$, e centenas de histórias trágicas de refugiados que não puderam entrar, conforme as pesquisas de Maria Luíza Tucci Carneiro. Neste sentido, não há dúvida de que a política do governo brasileiro foi conivente com o anti-semitismo na Europa. Embora o Estado Novo tivesse núcleos ideológicos afinados com regimes de extrema direita, como os de Portugal e Polônia, com o fascismo italiano e mesmo com o nazismo alemão, não se pode, no entanto, defini-lo como um regime fascista ou nazista, historiograficamente falando ${ }^{6}$.

O preconceito esteve presente na atuação da Ação Integralista Brasileira — movimento e partido fascista -, que existiu legalmente entre 1933 e 1937. O segundo líder em importância do partido, Gustavo Barroso, escreveu vários livros anti-semitas e traduziu para o português "Os Protocolos dos Sábios de Sião”. No entanto, o Integralismo, com exceção de Barroso, mantinha o preconceito como um ponto secundário e genérico, como está presente em Plínio Salgado e em Miguel Reale, referido a uma vaga e suposta ameaça internacional e não atacando especificamente os judeus no Brasil. Quando ocorria um ataque aos judeus no Brasil, como em Barroso, houve conflitos entre os dois líderes mais importantes do partido, e o próprio Barroso chegou a ser censurado por Salgado na imprensa integralista. O anti-semitismo era um ponto do ideário do movimento, mas não foi acionado localmente e não resultou em ações concretas.

Esta afirmação não tem o objetivo se atenuar o anti-semitismo, mas operar uma distinção: o preconceito presente em esferas do governo, do Itamaraty, do corpo diplomático, da ação da polícia política, no Integralismo e em círculos intelectuais não se transformou em ações concretas dentro do Brasil 
ou em violência aberta. Robert Levine escreveu que embora a propaganda anti-semita tenha aumentado após 1934, com o Integralismo e uma hostilidade oficial, "the threat remained potential, not actual. Brazilian jews never faced anti-Semitic violence. The general public reacted calmly to the commotion, and did not support the campaign instrumented by the domestic fascists ant other anti-Semitics". Além disso, "anti-semitism never won genuine popular support”. Para Marcos Chor Maio, não há evidências de que "a atuação da AIB, particularmente em relação aos judeus, tivesse promovido situações de tensões étnicas ou conflitos reais que alterassem o cotidiano da comunidade judaica no Brasil"?.

A pesquisa histórico-documental sugere caminhos interpretativos e uma abordagem que pode colocar questões bastante complexas sobre a relação entre história dos judeus e história do anti-semitismo. No caso da história contemporânea do Brasil, pode-se dizer que há pouca comunicação entre estas duas camadas de história, a dos judeus e a do anti-semitismo, por mais paradoxal que esta afirmação possa parecer. O historiador Jeffrey Lesser mostrou o mecanismo que permitiu ideologicamente ao Brasil restringir a entrada de novos imigrantes, ao mesmo tempo que não interferia na vida dos imigrantes que viviam no País. Ou seja, a "ameaça" estava referida aos imigrantes potenciais, não aos membros do grupo aqui residentes. No exterior, os judeus eram considerados semitas, portanto não-europeus e indesejáveis; uma vez no Brasil, eles eram brancos (não negros), portanto aceitáveis no contraste com uma sociedade cujo ideal de branqueamento era (é) central. Esta é a chave para compreender como uma política anti-semita contra os imigrantes pode justapor-se à inexistência de preconceito institucionalizado dentro do País. Lesser mostrou como mesmo as circulares secretas e as restrições não foram absolutas, mas foram burladas e sujeitas a negociação, o que permitiu inclusive que o número de imigrantes que entrou no País aumentasse em 1939, na vigência das circulares secretas, de acordo com a manipulação, ora negativa ora positiva, de estereótipos sobre o grupo.

Esta perspectiva é tão importante quanto a leitura da ideologia anti-semita expressa em centenas de documentos oficiais do Estado brasileiro à época. Fontes policiais tendem sempre a fazer crer que o mundo imaginado pela polícia existiu de fato tal qual esta o imaginava. É próprio da lógica policial, em qualquer época, ainda mais em uma ditadura, ver inimigos e acreditar na possibilidade de controle completo e total sobre os inimigos. A pesquisa em fontes policiais exige cuidados redobrados. A historiografia brasileira dos anos 1930 e 1940 tem enfatizado o aspecto totalitário da lógica policial e ideológica do Estado Novo, mas a lógica totalitária não se tornou hegemônica na sociedade. $\mathrm{O}$ fato de a polícia fichar centenas de pessoas e escrever dezenas de relatórios fascistas diz muito sobre o caráter ideológico da polícia e de setores 
do Estado, mas pode dizer muito pouco sobre o que efetivamente aconteceu a partir desta ação da polícia.

A memória coletiva da comunidade judaica enfatiza a centralidade do preconceito naquele período. A memória de vitimização tem sido bastante conveniente ao grupo em seus processos de formação de identidade em uma sociedade multicultural. Muitas vezes, ao se ler registros de memória de imigrantes, é difícil diferenciar uma postura mais recatada, receosa, assumida pelo imigrante diante do desconhecimento do Novo Mundo (e com sua própria experiência de vítima de preconceito e de perseguição na Europa), e visto com estranheza pela população local (mas não necessariamente com hostilidade), de uma postura - no caso do Brasil dos anos 1930 - que poderia ser interpretada como medo objetivo diante do Estado Novo e da ideologia xenófoba do regime de Getúlio Vargas. A memória pode associar, de forma anacrônica, a experiência de perseguição na Europa ao receio ou temor do imigrante ante o estranho, assumindo que teria havido de fato perseguição. Esta especulação genérica deve ser mais complexa no caso dos judeus alemães.

Vários fatores têm contribuído para que a compreensão do período do Estado Novo e da Segunda Guerra no Brasil seja dominada pela visão de uma comunidade aterrorizada, entre os quais se pode citar: a) o conhecimento público tardio, que se deu apenas nos anos 1990, relativo ao anti-semitismo no Brasil nos anos 1930, e aumentou seu impacto, já que o preconceito - agravado pelo conhecimento das circulares secretas - foi apresentado como uma face até agora desconhecida do período Vargas (a primeira lei imigratória com restrição à entrada de "semitas" foi a resolução secreta 1.137, de 7-6-1937); b) a virulência da expressão do preconceito em importantes setores do núcleo político e ideológico do governo de Getúlio Vargas e entre diplomatas brasileiros no exterior; c) a contraposição do anti-semitismo diante do persistente mito da cordialidade racial brasileira e do País acolhedor de imigrantes; d) a análise anacrônica deste anti-semitismo tendo o nazismo alemão e o Holocausto como cenários históricos de fundo, provocando comparações entre o Estado Novo e a Alemanha nazista, entre o anti-semitismo europeu, o Holocausto e o preconceito brasileiro.

\section{A VIDA INSTITUCIONAL JUDAICA ENTRE 1937 E 1945}

As instituições judaicas em São Paulo e no Rio de Janeiro acompanharam o desenrolar da guerra na Europa e formaram comitês de ajuda aos refugiados, que uniram as mais importantes entidades judaicas, embora a atividade em prol dos refugiados tenha ocupado apenas uma pequena parte das atividades assistenciais ${ }^{8}$. Esta atividade assistencial logo confundiu-se com 
uma atividade política, pró-aliados, pró-entrada do Brasil na guerra e, sem muita dissimulação, pró-sionista, no sentido de defender um Estado próprio para os judeus refugiados do pós-guerra.

As entidades judaicas realizavam suas atividades com bastante liberdade e pode-se afirmar - evidência empírica da leitura de jornais e atas de entidades daqueles anos - que o anti-semitismo no Brasil não era um tema central de preocupação dos imigrantes residentes no País. Uma declaração do presidente em 1942 era lembrada como evidência de que o Brasil estaria livre do preconceito. Em 22 de dezembro de 1942, o presidente Getúlio Vargas recebeu uma "delegação israelita" e condenou o anti-semitismo". O ano de 1942 foi um ano-chave naquele período, quando o País rompeu relações com o Eixo e depois declarou estado de guerra.

Durante as anos de guerra, as entidades judaicas funcionaram de forma corriqueira. Não há qualquer indicação de que a guerra, ou o temor à ditadura do Estado Novo tenham alterado o funcionamento cotidiano das entidades. Nenhuma entidade foi fechada ou sofreu intervenção. As eventuais dificuldades de abastecimento, especialmente no ano de 1944, como a falta relativa de produtos como combustível, farinha de trigo ou açúcar, afetaram os habitantes nos grandes centros urbanos, mas, de modo geral, pode-se dizer que o impacto da guerra no cotidiano brasileiro foi bastante relativo, não causando escassez absoluta de gêneros essenciais e nem tampouco um movimento de comoção nacional, mesmo quando o País enviou a Força Expedicionária Brasileira, em 1944, com 30 mil soldados, para lutar junto aos Aliados no norte da Itália ${ }^{10}$.

As principais entidades assistenciais judaicas de São Paulo, Sociedade Beneficente Israelita Ezra, Sociedade Beneficente Linath Hatezedek Policlínica, Organização Feminina Israelita de Assistência Social — Ofidas, escolas, sinagogas, entidades culturais, a Congregação Israelita Paulista (CIP) e seu movimento escoteiro Avanhandava, a Sociedade Cemitério Israelita de São Paulo, mantiveram sua atividade pública sem temor visível. Em 1943, 1944 e 1945, palestras, seminários e uma série de eventos ligados ao sionismo, à literatura hebraica e ao ensino de hebraico e de iídiche (língua falada pelos imigrantes da Europa Oriental) foram realizados abertamente em São Paulo e no Rio de Janeiro.

Uma cronologia das entidades daqueles anos mostra a atividade institucional do grupo em São Paulo. Em 1937 foi fundada a Sinagoga Israelita de Pinheiros Beth Jacob. No ano de 1940 foi fundado o Centro Israelita do Cambuci, que iniciaria a construção de uma sinagoga em 1941 e depois de uma escola. Ainda em 1940 foi fundada em São Paulo a Organização Feminina Israelita de Assistência Social (Ofidas), a partir da fusão de três entidades: Sociedade Beneficente das Damas Israelitas, fundada em 1915, Gota de Leite da B'nai Brith, 
fundada em 1933, e Lar da Criança Israelita (das Damas Israelitas), fundado em 1939. A Ofidas tornou-se uma referência no trabalho de assistência social, preocupada com a mulher, a família e a criança pobre ou imigrante.

Em 1941 foi fundada a Sociedade Sinagoga Israelita da Lapa, em São Paulo. Os estatutos regiam que "para os cargos administrativos só poderão ser eleitos sócios que saibam ler e escrever o português”, mas deixava claro que seus objetivos eram "a) construir, manter e cuidar, um templo para o culto hebraico" e "b) patrocinar e auxiliar o ensino da religião hebraica aos filhos dos seus associados". Ou seja, utilizando-se, em proveito próprio, da linguagem que restringia atividades "nacionais estrangeiras", o objetivo dos fundadores era manter o culto hebraico e ensinar a religião hebraica, termos aceitáveis ao Estado Novo e que, ao mesmo tempo, não feriam as intenções abertamente judaicas. Em junho de 1941 foi inaugurada em São Paulo a Sociedade Religiosa Israelita Asilo dos Velhos, criada formalmente em outubro de 1937. Em um relatório publicado em 1942, vê-se o cuidado na referência à preservação do judaísmo que, no entanto, é declarado explicitamente: entre os serviços oferecidos aos 60 asilados, está a "observação do rito religioso nesta casa, de acordo com os hábitos culturais e tradições religiosas dos velhos e velhas, tendo também uma biblioteca, jornais e livros sagrados" ${ }^{\prime 1}$.

A comunidade manteve pelo menos três programas de rádio no Rio de Janeiro e em São Paulo, em uma época em que o rádio era o principal meio de comunicação de massa e controlado pelo governo Vargas. Em 1943, no Rio de Janeiro havia pelo menos dois programas de rádio judaicos: o "Programa Israelita" na Rádio Guanabara, duas vezes por semana, e "A Hora Selecionada Israelita-Brasileira”, na Rádio Bandeirantes, diário. A programação incluía canções do "folclore israelita". Mesmo atenuado pelo "israelita", parece evidente que canções do folclore israelita não fossem em português, mas em línguas consideradas estrangeiras. O "Programa Israelita" anunciava na imprensa judaica um programa com músicas em iídiche. Em São Paulo havia pelo menos um programa judaico radiofônico, a "Hora Israelita", de Siegfreid Gothilf, cujas transmissões começaram em 1940 na Rádio Piratininga. Anúncios de comida judaica também eram publicados na imprensa, como o de que "come-se bem e idish no Lotar", no Rio de Janeiro. Em 1941, a exemplo de outros jornais publicados em línguas que não a portuguesa, os dois jornais em iídiche foram proibidos de circular, o Di Idishe Fokstsaitung, fundado em 1927, e Di Idishe Presse, de 1930. Contudo, a restrição ao uso de línguas estrangeiras parece não ter sido um constrangimento absoluto no caso do iídiche e do hebraico, salientando-se que o iídiche falado poderia facilmente ser confundido com o alemão. Em 1941, a editora e livraria Mosaik, de São Paulo, publicou Oisses Dertzlein (O que as letras contam, em iídiche), com o subtítulo de Realidade e Lenda na História do Alfabeto Hebraico, de Elias Lipiner, e em 
1942, Do Folclore Judaico, de Isaac Mishkiss, e História Elementar da Literatura Judaica, de Baruch Bariach, evidência de uma atividade editorial. Fernando Levisky mantinha uma "Coluna Israelita" no Diário de S. Paulo no ano de 1941. Em março de 1944, a revista Aonde Vamos? publicou anúncio de "aulas particulares de língua e literatura hebraica”. Em dezembro de 1944, um anúncio do Grêmio Lítero Esportivo de Nilópolis procurava um professor de iídiche para sua escola. A Sociedade Beneficente dos Israelitas Poloneses de São Paulo funcionou entre 1943 e 1945, mantendo atas em iídiche e tendo requerido vários alvarás de licença para espetáculos públicos e jogos, como xadrez, damas e dominó ${ }^{12}$.

Estes não são exemplos excepcionais, mas a corriqueira evidência de que durante os anos do Estado Novo e durante o período da Segunda Guerra Mundial funcionou com liberdade uma variada gama de instituições e atividades judaicas. As seqüências acima e a seguir não foram feitas desprezando-se as evidências em contrário.

\section{O PROJETO DE NACIONALIZAÇÃO E AS ESCOLAS JUDAICAS}

A educação e as escolas eram um dos pilares fundamentais do projeto cívico-pedagógico e da campanha de nacionalização do ministro da Educação e Saúde, Gustavo Capanema, um dos ideólogos do Estado-Novo. Neste sentido, a pesquisa sobre as escolas judaicas é um indicador expressivo. Mesmo diante do controle e da vigilância do Estado, pode-se afirmar que as escolas continuaram fazendo exatamente o que já faziam: ensinar judaísmo aos filhos dos imigrantes.

Entre 1937 e 1945, duas escolas judaicas iniciaram atividades em São Paulo: a Escola Israelita-Brasileira Luiz Fleitlich, em 1937 (anexa à Sinagoga Israelita do Brás), e o Ginásio Israelita-Brasileiro Chaim Nachman Bialik. O “israelita-brasileiro" era certamente a fórmula politicamente tranqüilizadora (da mesma forma que hebraico-brasileiro), mas os nomes Fleitlich, uma família local, e Bialik, o poeta hebraico, não deixavam dúvida sobre a procedência. As quatro escolas judaicas de São Paulo, que mantinham o ensino oficial ao lado do judaico, o que incluía Renascença (fundada em 1922) e Talmud-Thorá (fundada em 1935), funcionaram corriqueiramente.

Em 1940, o Centro Israel Talmud Thora Bet Jacob muda seu nome para Sociedade Brasileira de Instrução Religiosa Israelita. Segundo o novo estatuto, a entidade "resolve nacionalizar-se, em virtude das novas leis federais, renunciando manifestadamente a todos os postulados estrangeiros que o norteavam, passando, doravante a se chamar Sociedade Brasileira de Instrução Religiosa Israelita". Em seu artigo $1^{\circ}$, define que seu objetivo é "ministrar o 
ensino de religião Mosaica aos filhos dos seus associados, lado-a-lado com matérias de Cultura Geral, indispensáveis à cultura intelectual da mocidade". $\mathrm{O}$ artigo $4^{\circ}$ diz que "será edificado um templo para o culto da religião Mosaica, anexo à Escola". Por fim, o artigo $6^{\circ}$ do Capítulo 2 diz que para ser admitido como sócio, é necessário "professar a religião Israelita" e "ser proposto por dois sócios”. No ano de 1942, o Talmud-Thorá entrou com um processo para registrar uma professora particular de "língua hebraica", de nacionalidade polonesa, e o processo foi aprovado pelas autoridades de educação ${ }^{13}$. Ou seja, a escola "nacionalizou-se" e continuou a ensinar hebraico e conteúdos judaicos.

Em novembro de 1943, a diretoria do Renascença, que mantinha pré-escola e curso primário, autorizou o diretor da escola, Moyses Wainer, a requerer licença para abrir um curso ginasial (o que ocorreu em 1948), projeto que constituía um grande salto no trabalho da escola. Ao ler-se as atas de diretoria da escola entre 1941 e 1944, pode-se perceber claramente que - apesar da campanha de nacionalização que obrigou a escola a eleger uma diretoria de "brasileiros natos" em julho de 1942 -, a escola funcionou de forma normal, ensinando judaísmo, hebraico e iídiche. Em agosto de 1944, a diretoria solicitou ao inspetor da escola a prorrogação do prazo para mudar de nome, conforme solicitado em julho de 1944; na mesma reunião decidiu-se iniciar os procedimentos formais para abrir o curso ginasial. Em 1943, a escola mantinha pelo menos quatro professores, de um total de oito, para o ensino judaico, referidos como "professor de hebraico" e de "ensino religioso" ${ }^{14}$. No ano de 1945, iniciaram atividades duas escolas em São Paulo: o Colégio IsraelitaBrasileiro Iavne Beit Chinuch e o Seminário Hebraico Renascença de Professores, primeiro curso para professores do ensino judaico. Em 18 de janeiro de 1945, o diretor do Gymnasio Renascença publicou artigo na revista Aonde Vamos? sobre a pretendida criação de uma cadeira de estudos hebraicos na Universidade de São Paulo, que tinha o estudo da língua hebraica como um dos pilares.

O exame de um livro de visitas da Escola Israelita Brasileira Luiz Fleitlich, entre julho de 1937 e outubro de 1945, constitui singular aproximação com a situação política do Estado-Novo ${ }^{15}$. No primeiro registro, de 27 de julho de 1937, o inspetor escolar anota que a escola funcionava regularmente com 50 alunos matriculados. Na segunda visita, em 11 de março de 1938, registra que entre as irregularidades estava a de "professores lecionarem idioma estrangeiro no $1^{\circ}$ ano, professores não registrados regendo classes”. Nesta visita, o inspetor deixou à diretoria as seguintes determinações a serem postas em prática imediatamente: “a) não permitir o ensino de língua estrangeira, nem mesmo religião, aos menores de 10 anos, ou a analfabetos em qualquer idade; b) providenciar o registro dos professores na chefia de serviço, dentro 
do prazo de oito dias a contar desta data; c) organizar o horário escolar em duas vias sendo uma enviada à chefia de serviço, incluindo durante o período escolar, de preferência na $2^{\circ}$ aula, o ensino de língua estrangeira, que não deverá exceder de um quarto do dia escolar, ou seja, que não deverá exceder 40 minutos, três vezes por semana; d) comunicar à chefia de serviço qualquer modificação de horário, ou no corpo docente, não dando posse aos novos professores sem a competente autorização da chefia".

Ainda no registro do dia 11 de março de 1938, anotou o inspetor escolar que "os alunos que freqüentam a escola para receber apenas o ensino de língua estrangeira deverão apresentar à diretora um atestado do diretor ou professor do curso que freqüentam, contendo os seguintes dados: nome, idade, dia, mês e ano de nascimento e classe que freqüentam. $\mathrm{O}$ atestado em apreço deverá ter a firma reconhecida". Na quinta visita, em 12 de julho de 1937, o inspetor registrou uma "certa irregularidade": uma senhora estrangeira como auxiliar de jardim de infância e uma "classe de $1^{\circ}$ ano entregue a professora estrangeira". O inspetor determinou o afastamento das mesmas e que "a classe do $3^{\circ}$ ano tenha aula de hebraico das 14 às 14:40". Na visita seguinte, em 15 de julho, o inspetor deixou registrada a determinação de "comemorar com toda a solenidade o dia da Pátria, 15 e 19 de novembro", e anotou que a "senhora Frida Bekin poderá lecionar hebraico a maiores de 10 anos alfabetizados, visto ter sido solicitado o seu registro para lecionar essa disciplina”. Mais 41 visitas foram registradas no livro até 10 de outubro de 1945. Em 31 de outubro de 1940, por exemplo, o registro informa que o professor de "religião" é o senhor José Schoichet. Em 19 de novembro de 1942, o inspetor anotou que "visitando, hoje, esta escola, tive o prazer de encontrá-la em comemoração à Bandeira Nacional”. Não há nas 41 visitas posteriores a 15 de julho de 1938 , até 1945, qualquer indicação de problemas maiores com a escola, além das recomendações acima registradas.

Este documento pode ser lido como a manifestação visível do controle nacionalista e xenófobo exercido pelas autoridades de educação — uma das áreas que o Estado Novo pretendia reformar para a construção do "novo homem brasileiro". Mas pode-se ler este livro como a documental evidência de como este processo é mais complexo e ambivalente do que a leitura do preconceito e do controle estatal. A despeito do Estado, da lei da ideologia, a escola funcionou de forma regular entre 1937 e 1945, ensinando religião, judaísmo e hebraico aos seus alunos. Estava claro para o inspetor que uma parte dos alunos freqüentava a escola para aprender uma "língua estrangeira", o hebraico. As admoestações do cordial inspetor jamais redundaram em qualquer sanção mais grave, nem mesmo uma anotação mais séria. A escola, por sua vez, contratou professores imigrantes e procurou dar-lhes registro oficial de trabalho. 


\section{O DECRETO DE 1938 E A PROIBIÇÃO DO SIONISMO}

A restrição às atividades sionistas no Brasil tem sido largamente referida como evidência do clima hostil e mesmo de anti-semitismo naquele período. No entanto, como veremos, a restrição foi formal ou, ao menos, não efetivada e, mais importante, pode não ter passado de um relativo mal-entendido que, por outro lado, permitiu às instituições a promoção de atividades sionistas e ao governo acreditar que havia, de fato, proibido as ideologias "estrangeiras" no País.

A proibição legal das autoridades federais à existência de um movimento sionista no Brasil não foi uma restrição específica anti-judaica, mas a conseqüência de um decreto nacionalista visando proibir "movimentos subversivos internacionais". O Decreto-Lei n ${ }^{\circ} 383$, de 1938, proibia aos "estrangeiros" atividades de natureza política e organizar sociedades, fundações, companhias, clubes, de caráter político de partidos “do país de origem”, considerados estrangeiros. $\mathrm{O}$ decreto determinava que era permitido aos "estrangeiros associarem-se para fins culturais, beneficentes ou de assistência, filiarem-se a clubes e quaisquer outros estabelecimentos com o mesmo objetivo, bem assim reunirem-se para comemorar suas datas nacionais ou acontecimentos de significação patriótica”. Reuniões requeriam prévia autorização policial. A lei era ambígua e dava espaço a ampla margem de atividade. O decreto era provavelmente dirigido contra movimentos de esquerda, especialmente o comunista, que fora responsável por uma tentativa de golpe de Estado em 1935. Havia, por parte do Estado-Novo, uma cadeia associativa entre judeus e comunismo, como evidencia o forjado Plano Cohen (nome associado a Bela Kuhn), suposta conspiração para tomar o poder e que serviu como pretexto para o golpe do Estado-Novo em 1937.

É possível que a proibição oficial de que o sionismo teria sido alvo tenha sido uma medida reativa possivelmente precipitada pela própria Federação Sionista. Esta antecipou-se em suspender suas atividades diante do decreto de 1938. Uma carta do secretário geral de um movimento sionista de Buenos Aires, ao executivo do movimento em Londres, datada de 6 de agosto de 1938, diz, baseada na visita de um emissário que visitou o Brasil (na tradução do iídiche, de Nachman Falbel), que "o decreto contra as atividades de organizações estrangeiras foi, como vocês sabem, dirigido exclusivamente contra os nazistas. Por razões óbvias o decreto assumiu um caráter geral e legalmente foi aplicado a todas as atividades estrangeiras. Ao mesmo tempo temos que enfatizar que não há anti-semitismo no Brasil, apesar de que agentes alemães tenham ocupado várias posições em diversos níveis do governo, e tenham exercido, inoficialmente, uma influência considerável". Para o signatário da carta, "infelizmente a comunidade judaica entrou, desnecessariamente, em 
pânico. Daí surgiu a tendência de transformar as instituições judaicas em uniões brasileiras de fé mosaica" ${ }^{16}$. A carta afirma ainda que as entidades sionistas em São Paulo e no Rio de Janeiro conseguiram legalmente manter suas atividades após o decreto, mas a Federação Sionista do Brasil precipitou-se e fez uma declaração pública de que iria suspender suas atividades por causa do decreto (o que não foi exigido), o que acabou criando suspeitas nas autoridades. A federação então mudou seus estatutos, desvinculando-se da sede em Londres, e assumindo que era um movimento brasileiro pró-Palestina para fins religiosos e caritativos para com os judeus da Europa. Mas o governo brasileiro, então, recusou a autorização de funcionamento.

É possível sugerir que a proibição das atividades sionistas tenha sido resultado de uma precipitação da própria Federação Sionista em suspender suas atividades, e que o decreto de 1938 não levaria a isso. O testemunho, sobre os anos posteriores a 1937, de Samuel Malamud, conhecido memorialista da presença dos judeus no Rio de Janeiro e um dos principais dirigentes do sionismo desde os anos 1930, além de ter sido o primeiro cônsul do Estado de Israel no Rio, aponta na mesma direção: "apesar de posto na ilegalidade pelo Estado Novo em 1937, o movimento sionista no Brasil e os seus dirigentes continuaram a reunir-se para trocar idéias e manter o trabalho de divulgação e arregimentação. Não se pode dizer que as reuniões se realizaram com absoluto desconhecimento das autoridades policiais. Os encontros eram tolerados" ${ }^{17}$. Segundo Malamud, apesar da Revolução de 1930, do levante comunista de 1935, da tentativa de putsch integralista de 1938 e até o decreto de 1938, "o movimento sionista brasileiro continuava a desenvolver as suas atividades em todo o País e, ao mesmo tempo, revidava o anti-semitismo, que uma parte da Ação Integralista procurava disseminar”. Ou seja, além de desenvolver suas atividades, havia uma postura de enfrentamento público do preconceito.

Conforme as memórias de Fiszel Czeresnia, importante ativista sionista em São Paulo, com a proibição do movimento, "como as organizações de auxílio às vítimas israelitas conseguiam desenvolver seu trabalho sem problemas, alguns militantes, inconformados com a proibição getulista, fundaram o Centro Hebreu-Brasileiro, uma instituição aparentemente assistencial tanto é que de seu registro constava, entre parênteses, a qualificação de 'órgão ligado e registrado junto à Cruz Vermelha Brasileira' -, mas que, nos bastidores, atuava em política. De um lado, arrecadava fundos para os sobreviventes; de outro, trabalhava para o movimento sionista" ${ }^{18}$. Ao comentar o que considerava como proibição do sionismo, Czeresnia a situa "após a entrada no Brasil na guerra, ao lado dos aliados”, o que não poderia ser anterior à declaração de guerra em 1942, portanto quatro anos após o decreto de 1938. O Centro Hebreu-Brasileiro, de linha sionista, estava bastante ativo em 1944.

O grupo Shalshelet (“corrente”, em hebraico), dissidência juvenil sionis- 
ta, fundado em São Paulo em 1944 a partir de uma cisão da Avanhandava, movimento escoteiro da Congregação Israelita Paulista, escrevia suas atas em alemão e fazia atividades ao ar livre, cantava canções hebraicas e organizava cursos e atividades sionistas. Em janeiro de 1945 estava ativo um Comitê Weizman que se reuniu para organizar uma campanha para "comprar terras na Palestina”. Em abril de 1943, a Biblioteca Israelita Haim Nachman Bialik, localizada na Praça da República, centro da então capital federal, fez uma homenagem ao segundo aniversário da morte do líder sionista Max Nordau, e foi lido seu discurso no $8^{\circ}$ Congresso Sionista em Haag. A Biblioteca era o nome que havia assumido o movimento sionista Hatchya ("renascença", em hebraico) a partir de 1937. No mesmo mês, abril de 1943, o Ginásio HebreuBrasileiro, uma das principais escolas judaicas do Rio de Janeiro, festejou a "páscoa israelita" no salão do templo, sendo que a reunião foi aberta com o Hino Nacional e fechada ao som do Hatikva ("esperança", canção hebraica que se tornaria o hino do Estado de Israel). Em abril de 1944, a revista judaica do Rio de Janeiro Aonde Vamos? publica uma capa com a imagem de um halutz (imigrante sionista) na Palestina com o título "Conseqüência da Vitória”, aberta adesão à causa sionista. Em junho de 1944, após uma visita pública ao Rio de Janeiro do delegado da Universidade Hebraica de Jerusalém, foi anunciada doação, via Banco do Brasil, à universidade por uma entidade denominada Amigos da Universidade Hebraica de Jerusalém. Essa tolerância oficial certamente explica a presença de autoridades do primeiro escalão, como o ministro Gustavo Capanema, na primeira atividade pública de cunho sionista em março de 1945, no Rio de Janeiro, um banquete em homenagem ao líder sionista Chaim Weizmann, quando o movimento ainda era formalmente ilegal, o que só foi revogado em julho de 1945.

Com a liberdade religiosa e cultural, social e institucional, e a possibilidade de ascensão social, a população judaica de São Paulo pôde afirmar publicamente e com altivez uma identidade judaica e brasileira, e foram os anos 1930 e 1940 que criaram as condições para um verdadeiro boom de atividades institucionais, sociais, culturais e políticas iniciadas ainda em 1945. Em um espaço de não mais do que dois ou três anos, surgiram organizações sionistas, movimentos juvenis, movimentos judaicos de esquerda, jornais e revistas, inúmeras associações de ajuda a refugiados e, em 1946, a Federação das Sociedades Israelitas Brasileiras do Estado de São Paulo, que passou a coordenar as entidades judaicas. A criação da Federação Israelita em 1946 evidencia uma importante passagem para a tentativa de criar em São Paulo uma comunidade centralizada e de orientação sionista. 


\section{OPORTUNIDADES ECONÔMICAS E ASCENSÃO SOCIAL}

Os anos entre 1937 e 1945 foram anos de oportunidades de ascensão econômica para imigrantes em São Paulo e no Rio de Janeiro, e em outros centros, com ocupações urbanas, profissões liberais e ofícios especializados, que encontraram oportunidades profissionais e comerciais diante da acelerada urbanização, da industrialização, das atividades de comércio, perante as restrições às importações, e das possibilidades de desenvolvimento abertas na indústria e no comércio locais. O comércio dos mascates ou prestamistas foi também um importante meio de ascensão social dos imigrantes, que tinham uma Cooperativa de Crédito Popular, fundada em São Paulo em 1929. É importante salientar que não havia restrições formais à ascensão social e econômica dos imigrantes na sociedade.

Evidentemente, estas possibilidades de ascensão estavam ligadas não a qualquer características étnica, mas ao perfil urbano dos imigrantes, à sua formação escolar e profissional prévia, ao fato de terem se concentrado em cidades, às condições e oportunidades objetivas do desenvolvimento urbano e industrial, e à forma de organização comunitária, que favoreceu e estimulou o desenvolvimento destas atividades. Os estereótipos sobre os judeus foram manipulados e, quando interessava politicamente, os imigrantes passaram a ser vistos como imigrantes com aptidões interessantes ao desenvolvimento econômico do País ${ }^{19}$.

Em São Paulo, um grupo de empresários fundou em 1944 a Associação dos Comerciantes e Industriais de Tecidos e Artefatos de São Paulo (Acita), uma associação patronal no ramo têxtil formada exclusivamente por empresários judeus, conforme os nomes da primeira diretoria e do conselho consultivo. A associação era considerada "inédita” na comunidade, "pois congrega a quase totalidade dos comerciantes e industriais de tecidos e artefatos, representando uma parte notável da indústria e comércio bandeirante". Bandeirante utilizado como sinônimo de paulista (em lugar de São Paulo) mostra a amplitude dos negócios intencionados e a consciência da dimensão dos negócios de proprietários do grupo no ramo têxtil. Mostra ainda que não havia receio por parte de empresários em fundar uma associação exclusivamente étnica em novembro de 1944. Nos objetivos da entidade, não havia qualquer referência a alguma atividade de âmbito cultural étnico, mas objetivos comerciais que, segundo o presidente, eram "conferir à Acita cada vez mais extensa representação perante os poderes públicos e as entidades congêneres, e criar novos departamentos na medida das crescentes necessidades da classe" 20 .

Sobre os imigrantes judeus italianos que vieram ao Brasil após as leis anti-semitas na Itália em 1938, Angelo Trento escreveu que "o mundo do trabalho acolheu-a de braços abertos, inclusive o mundo italiano, apesar do seu 
fascismo ostensivo. Quem mais utilizou a colaboração dela - e não por acaso - foi a família Matarazzo, que empregou vários judeus imigrados. Se a inserção dos técnicos na sociedade brasileira apresentou poucas dificuldades, menor ainda registraram os comerciantes. E, terminada a guerra, uns e outros não voltaram mais à Itália, talvez por causa do patrimônio e do prestígio adquiridos". Igualmente, vários professores universitários "não tiveram a menor dificuldade para conseguir emprego nas faculdades locais e em institutos de pesquisa" ${ }^{21}$. Um dos exemplos mais interessantes é o de Giorgio Mortara, estatístico e diretor de prestigiosas publicações de economia e estatística na Itália. Afastado dos cargos que ocupava em 1938, emigrou ao Brasil a convite do presidente do Instituto Brasileiro de Geografia e Estatística (IBGE) e coordenou o censo de 1940. Assim, observa-se que um imigrante, refugiado do fascismo, tornou-se o coordenador do censo brasileiro de 1940, em um período em que se discutiam intensamente no País os parâmetros "desejáveis" de povoamento.

\section{ESTRATÉGIAS SEMÂNTICAS: SUBSTANTIVO OU ADJETIVO?}

As entidades judaicas sofreram as mesmas restrições formais que outras entidades consideradas estrangeiras, que foram forçadas a "nacionalizar" seu nome e eleger uma diretoria de "brasileiros natos", entre as quais entidades ligadas à imigração italiana, alemã, síria, libanesa, japonesa ${ }^{22}$, judaica e outros grupos. Embora a lei sobre o que significa "nacionalizar" não fosse muito clara, sua direção ideológica era xenófoba e tinha como ideário a criação de uma nacionalidade que pudesse ser considerada autenticamente brasileira. Este era o projeto de educação e cultura de Gustavo Capanema que, embora agrupasse intelectuais de esquerda em seu ministério, tinha uma visão próxima ao fascismo. Não obstante muito referido, este processo de nacionalização ainda é pouco estudado e conhecido em seus efeitos concretos.

No caso das entidades ligadas à imigração judaica - e sem generalizar esta afirmação a outros grupos -, este processo não teve maiores conseqüências que a mudança de nome das entidades e de diretorias. As entidades adaptaram-se a este processo sem maiores receios. Mas, mais do que adequar-se às leis nacionalistas, estas instituições criaram estratégias para adaptar-se sem abdicar de suas funções e sem submeter-se à intimidação. Algumas dessas estratégias eram ativas e engenhosas, especialmente pela aparência de eficiente simplicidade.

Diante das novas leis e da negativa no sentido de obter isenção do imposto predial em São Paulo - porque a entidade atenderia apenas crianças judias ou atenderia crianças daquele grupo em maior número do que de ou- 
tros grupos -, a Ofidas cogitou mudar o nome de sua creche de Lar de Crianças Israelitas para Lar Israelita de Crianças ${ }^{23}$. Enquanto Lar de Crianças Israelitas qualifica as crianças, indicando que o atendimento é exclusivo, Lar Israelita de Crianças qualifica a instituição, sugerindo uma entidade mantida pelo grupo, mas que pode atender a população em geral. Embora a diferença - aqui acentuada - pareça grande, uma leitura apressada dos nomes mal faria notar a distinção, tão sutil e econômica em sua engenhosidade e, o que importa, política e legalmente eficiente. Este é um caso emblemático de como uma troca de palavras, em uma trama gramatical e semântica, pode resolver uma situação que, no limite, poderia colocar em risco a entidade. A documentação disponível não confirma se a mudança ocorreu efetivamente, mas a proposta da mudança aponta a estratégia (a prefeitura acabou não aceitando a isenção).

Em maio de 1940, a Sociedade Beneficente Linath Hatzedek Policlínica — fundada em 1929 e que funcionava como um ambulatório médico dos imigrantes no Bom Retiro, em São Paulo - mudou seu nome para Sociedade Linath Hatzedek (Auxílio Santo). Auxílio Santo, tradução aproximada de Linath Hatzedek (em iídiche), tinha como objetivo dar um nome "brasileiro" à entidade. $\mathrm{O}$ nome ganhou um complemento em português, auxílio santo, mas em parênteses e como tradução secundária e complementar. Em agosto de 1940, mudanças mais profundas foram exigidas pelas autoridades, como a alteração para um nome de "ressonância nacional". Na reunião de 18 de fevereiro de 1941 houve uma longa discussão até que se chegasse à seguinte solução: Policlínica Auxílio Santo Mantida pela Sociedade Beneficente "Linath Hatzedek". Em 1942, o diretor do Serviço de Medicina Social propôs o nome de Policlínica Auxílio Santo, uma das condições para conceder isenção de taxas. Um impresso da entidade da década de 1940 mostra o nome Linath Hatzedek muito maior e identificado claramente como o nome da entidade e, muito menor, "Auxílio Santo". Em maio de 1940, a Policlínica também alterou o estatuto: onde estava escrito "compõe-se de ilimitado número de sócios, exclusivamente israelitas", escreveu-se: “compõe-se de sócios de qualquer nacionalidade, pertencentes à Religião Israelita”. Igualmente, se para ser sócio era "necessário ser israelita, maior de 18 anos, de ambos os sexos", agora era necessário ser maior "de 18 anos, de qualquer nacionalidade e sexo, que professem a Religião Israelita”. Dessa forma, "exclusivamente israelita” tornou-se "qualquer nacionalidade pertencente à Religião Israelita", o que atendia formalmente à exigência de "nacionalidade", mas preservava a especificidade judaica. Novamente, um sutil jogo de palavras e de identidades foi engendrado para adequar-se às autoridades, sem concessão de fato.

Em agosto de 1940, mais mudanças foram exigidas e a policlínica fez uma assembléia geral extraordinária para efetuá-las e eleger a diretoria para o pe- 
ríodo 1942-1944. A assembléia teve início da seguinte forma: "Pede a palavra o Sr. Bidlowsky que inicia a sua oração em idioma 'yidish'. O Sr. Presidente aparteia e dirigindo-se à Assembléia pede que os oradores se pronunciem em Português, dada a legislação em vigor, a respeito". Em seguida, a diretoria explica que "a Sociedade se destina a prestar assistência médico-ambulatorial exclusiva e indistintamente a todos os indigentes, sem distinção de nacionalidade ou crença religiosa e a título inteiramente gratuito". Segundo as exigências das autoridades, na entrada da sede deveria estar escrito em uma placa: "Serviço médico gratuito para os pobres". Em fevereiro de 1941 voltou-se ao tema da troca de nome, "não somente para atender às atuais leis de caráter nacionalista, bem como por corresponder ao solicitado pelo Serviço de Medicina Social", para ser isento de taxas. As autoridades reconheciam que a "Sociedade se destina a prestar assistência médico-ambulatorial exclusiva e indistintamente a todos os indigentes, sem distinção de nacionalidade ou crença religiosa e a título inteiramente gratuito", sendo necessário colocar a placa "Serviço médico gratuito para os pobres". Registra o documento das autoridades médicas que se trata "de uma sociedade que vem ao encontro dos interesses de indigentes desprotegidos da sorte e instalada em país liberal e acolhedor como o nosso, sem visar nenhum lucro ou interesse pecuniário".

Em janeiro de 1942, mês em que o Brasil rompeu relações diplomáticas com a Alemanha, a entidade recebeu intimação da Superintendência da Ordem Política e Social com diversas exigências para a identificação da Sociedade e de seus diretores. Mesmo diante dessa carta, o presidente da policlínica decidiu seguir um a um todos os trâmites legais internos à entidade para cumprir as novas leis governamentais - sem submeter-se aos prazos estipulados pela polícia - e convocar uma assembléia geral para informar os diretores da determinação de eleger uma nova diretoria, além de aprovar o balanço geral, prestar contas e manifestar-se sobre a modificação nos estatutos sociais, conforme imposto pela polícia. Em 2 de março de 1942, além do prazo legal exigido, reuniu-se uma assembléia, na segunda convocação, quando havia o número legal de sócios, "quites com os cofres sociais" e realizou-se, afinal, a eleição com a presença do representante da Superintendência, que interveio nas discussões e pediu ao presidente da entidade que alterasse mais um item do estatuto, para que se incluísse após a palavra administrador a palavra "brasileiro", no artigo 26. O presidente esclareceu à reunião que esta era apenas uma sugestão, não uma exigência do representante. Então foram "formuladas diversas perguntas sobre se o acréscimo deva ser somente do adjetivo brasileiro ou da expressão qualitativa 'brasileiro nato"'. Esclareceu-se que somente do "brasileiro". Um sócio sugeriu que se eliminasse do estatuto o cargo de administrador, mas a proposta foi recusada. Decidiu-se, então, votar a exclusão do "substantivo administrador" ou inclusão do "adjetivo 'brasileiro"”. Pro- 
pôs-se uma votação nominal. O presidente da entidade disse que em onze anos como presidente nunca tivera necessidade de recorrer à votação nominal. "Por absoluta maioria", todos concordam em incluir o "adjetivo brasileiro" após o "substantivo administrador". Na reunião seguinte, no entanto, a exemplo do que ocorreria em todas as reuniões subseqüentes, os diretores anteriores, a começar pelo ex-presidente, compareciam normalmente às reuniões de diretoria, junto com os novos diretores. E, mais importante, o expresidente foi nomeado administrador, e isto depois de toda a discussão sobre o substantivo e o adjetivo ${ }^{24}$.

No caso da Sociedade Israelita de Beneficência "Ezra”, a estratégia para adequar-se à legislação também foi engenhosa. A Ezra, fundada em 1916, foi a principal entidade local dos judeus em São Paulo até pelo menos 1946, com a criação da Federação Israelita. A Ezra cuidava de todo o processo legal, social e econômico de entrada, inserção e manutenção dos imigrantes e dos residentes locais que precisassem de auxílio. Uma alteração nos estatutos registrada no ano de 1946 passa a definir no Capítulo 1, artigo $1^{\circ}$, que a Ezra é composta de "ilimitado número de sócios de ambos os sexos, de qualquer nacionalidade, pertencentes à religião Israelita”. No Capítulo 2 , Artigo $2^{\circ}$, sobre a admissão de sócios, diz que somente poderão ser admitidos como sócios da Sociedade "os maiores de 18 anos, de qualquer nacionalidade e sexo, que professem a religião israelita" ${ }^{25}$. Há neste estatuto provavelmente um eco das restrições do Estado Novo, um jogo entre "nacionalidade" e "religião" que poderia passar despercebido, não fosse ele uma eficiente estratégia que, ao enfatizar religião em detrimento de nacionalidade, adequava-se às restrições do Estado Novo sem, de fato, alterar, do ponto de vista interno à entidade, nenhuma cláusula importante.

\section{O SILÊNCIO COMO ESTRATÉGIA}

Entidades como a B'nei B'rith ${ }^{26}$, de cunho social e cultural, e a Sociedade Cemitério Israelita de São Paulo deixaram de registrar atas em seus livros de atas entre 1941 e 1944 (no caso da Sociedade Cemitério, entre o período de 20 de abril de 1934 e 4 de setembro de 1940 há uma única ata encontrada, de 20 de agosto de 1936). A Sociedade Cemitério manteve atividades durante estes anos e foram realizados enterros com inscrições em hebraico nas lápides, a exemplo do que já era feito. Uma referência na ata de 1945 fala da situação "anormal" das reuniões entre 1941 e 1944, sem especificar. Em $1^{\circ}$ de fevereiro de 1945, um diretor, segundo a ata, "propõe, dada a situação anormal com que vêm sendo realizadas as reuniões de diretoria, e tendo em vista a suges- 
tão do Sr. Presidente, propõe que se faça o mais cedo possível a convocação da assembléia para a eleição de nova diretoria".

Duas questões surgem em relação à Sociedade Cemitério. A primeira delas seria perguntar por que a entidade absteve-se de manter atas formais, ao menos no livro de atas registrado legalmente, posto que ela continuou funcionando aparentemente de forma regular. Segundo: o que significa a situação "anormal" a que se refere a ata de 1945, e qual foi o impacto que esta situação efetivamente teve sobre a entidade, admitindo-se que não foi por simples "temor" ao Estado Novo e diante da Segunda Guerra que uma entidade deixou de manter registros (já que ela manteve sua atividade), e que, talvez diferentemente de outras entidades, fatores específicos tenham constrangido a Sociedade Cemitério. Seria possível manter registros apenas formais e adequar-se aos requisitos legais ou então, a exemplo de outras entidades, seria possível eleger uma nova diretoria de "brasileiros natos", de fachada, e fazer as adequações necessárias.

Cabe então aventar que, de qualquer forma, outra foi a estratégia adotada pela Sociedade Cemitério. Uma hipótese é que o clima político intimidatório e anti-estrangeiro implicou maior visibilidade da entidade ou temor de que isso pudesse ocorrer, por ser um dos poucos cemitérios privados da cidade, o que talvez fosse a exacerbação de um receio prévio que já inibia, anteriormente, o registro de atas. Se o temor não era policial, pode-se sugerir que o receio fosse o de perder o direito a um cemitério privado em separado (conquista recente) e o do controle financeiro, sendo que possivelmente parte das contas era mantida de forma informal pela diretoria, um grupo bastante fechado, que não as queria submetidas à ingerência do governo e talvez da própria comunidade judaica. A Sociedade Cemitério tinha, nos anos 1940, um bom patrimônio financeiro, o que permitiu que ela auxiliasse inúmeras outras instituições da comunidade naquele período ${ }^{27}$. Deixar de manter registros pode significar ter mantido um perfil discreto de atuação durante aqueles anos, deixando talvez, inclusive, de manter reuniões públicas formais. $\mathrm{Ou}$ seja, a ausência de atas formais pode sugerir que a entidade ficou como que dormitando formalmente entre 1941 e 1945 para chamar o mínimo de atenção, do ponto de vista econômico, e poder manter sua função essencial - o que era o mais importante - sem atrair controles ou fiscalizações. Esta poderia ser uma explicação mais pragmática. Igualmente, pode-se pensar que a Sociedade Cemitério não quis se submeter a substituir sua diretoria por "brasileiros natos", como ocorreu com outras entidades, mantendo a diretoria que talvez se manifestasse irredutível a uma substituição, mesmo que de fachada, talvez pelas características da entidade e porque os fundadores eram um pequeno núcleo que não queria ampliar-se na comunidade, mesmo em um contexto político desfavorável. Caso estas duas hipóteses, que podem ser com- 
plementares, façam sentido, elas representariam uma outra forma de estratégia durante o período do Estado Novo. A falta formal de registros de atas pode revelar uma estratégia de ficar dormitando como entidade, passar a uma espécie de limbo legal — sem tornar-se ilegal, o que é distinto - e simplesmente deixar passar o tempo até que a situação pudesse se reverter.

Já no caso da B'nei B'rith, a entidade era formada por imigrantes, muitos da Alemanha, que tinham galgado certo status social e mantinham uma entidade que se pretendia inserida, como se vê pela programação, entre as quais se pode encontrar palestra sobre psicanálise no início dos anos 1930. Sua sede era no elegante Edifício Esther, na Praça da República, e depois na Rua Maranhão, no bairro de Higienópolis. A B’nei B'rith era uma entidade cultural e social, não cumprindo uma função, por assim dizer, essencial, do ponto de vista comunitário. Conforme os estatutos definidos nos anos $1930 \mathrm{e}$ publicados em 1939, a Irmandade B'nai B'rith tinha como objetivo "unir todos os Israelitas no trabalho de cultivar os seus mais elevados ideais, assim como os de toda a humanidade; desenvolver e elevar as suas qualidades éticas e intelectuais e desenvolver a sua cultura judaica, neles despertando os mais puros princípios de patriotismo, honra e filantropia; amparar a ciência e a arte; ir ao encontro dos pobres e dos necessitados, visitar e cuidar os doentes; proteger e auxiliar a viúva e o órfão segundo os mais altos princípios de humanidade". Ou seja, seu objetivo era cultural e social, uma alavanca de integração e de difusão de uma imagem integrada dos judeus brasileiros. Assim, sua eventual inatividade durante os anos de guerra, ou simplesmente atividade sem registro de atas, pode indicar uma atuação discreta ou, como no caso da Sociedade Cemitério, uma forma de resguardar-se sem chamar a atenção. No caso específico da B’nei B’rith, entretanto, é mais plausível que, por não ter atividade essencial, a entidade tenha ficado em um nível mais discreto de atuação, talvez até inativa, talvez para não pôr em risco a própria inserção social almejada de parcela da comunidade judaica que preferia não correr riscos em sua inserção no País.

\section{DIRETORIA DE FACHADA}

Outras estratégias foram efetuadas, como é o caso da Congregação Israelita Paulista, entidade fundada por imigrantes judeus alemães em 1936, refugiados do nazismo, e também judeus italianos que deixaram o país por causa das "leis raciais" de 1938. Neste caso, trata-se certamente do grupo de imigrantes mais vulneráveis, objetivamente à ação do Estado-Novo, em especial após o início da guerra e a declaração de guerra do Brasil aos países do Eixo.

Em 16 de agosto de 1939, a Assembléia dos Representantes da CIP con- 
vocou uma reunião para eleger três novos membros da diretoria diante da exigência de eleger uma diretoria de "brasileiros natos". A carta especificava quais três diretores aceitaram se demitir e quais três assumiriam os três lugares vagos. No mesmo dia, outra carta assinada pelo presidente da assembléia e por um diretor é endereçada à diretoria e aos membros da assembléia, convocando a diretoria para se reunir após os representantes, tendo como ordem do dia a "coopção de 3 membros colaboradores sem direito de voto", que eram os mesmos três que se demitiram na outra carta. Ou seja, eles seriam reconduzidos formalmente, do ponto de vista da CIP, mas não votariam para manter-se a adequação de fachada à legislação.

Em 27 de janeiro de 1942, a diretoria e a Assembléia dos Representantes elegeram uma diretoria composta de seis "brasileiros natos", modificando o estatuto, de forma que a congregação passaria a ser administrada por uma diretoria de seis membros eleita pela Assembléia dos Representantes. Duas semanas depois, em 10 de fevereiro de 1942, a assembléia criou um sistema de comissões por área de trabalho que passariam a dirigir a entidade. Foram criadas 14 comissões, cada qual com um presidente e membros integrantes. Até 1945, quando foi eleita uma diretoria livre, não foi possível localizar no acervo da CIP as atas de reunião da diretoria escolhida em janeiro de 1942. Já as atas de reuniões das comissões ocupam a periodicidade e a função que eram incumbência de uma diretoria. A CIP, cumprindo a obrigação legal de eleger uma diretoria de "brasileiros natos", criou outra estrutura de direção, outra diretoria, e esta administrou efetivamente a entidade durante os anos de 1942 a 1944, que cobrem o rompimento de relações com o Eixo e a entrada militar do Brasil na guerra.

Os membros da CIP preocuparam-se e até alarmaram-se com a atmosfera e as medidas legais contra os cidadãos dos países do Eixo, medidas que não apresentavam qualquer exceção em relação aos refugiados judeus. Em 1938, a CIP tinha mais de 800 sócios. Poucos dias após a invasão da Polônia pela Alemanha, em uma reunião da assembléia dos representantes, o médico Luiz Lorch, fundador e membro mais proeminente, falou "sobre a preocupação daqueles que ainda não conseguiram regularizar sua situação. No meio dos recém-chegados reina medo e desespero". Outro representante pediu a todos para "fazer tudo quanto for possível para que os imigrados radiquemse, observando a mentalidade do povo brasileiro, observando principalmente as leis do País, evitando qualquer infração dessas leis". Apesar do clima de "medo e desespero" referido, não há referência na documentação pesquisada a ações contra os imigrantes, embora os membros que viveram essa época contem histórias de constrangimentos, de salvo-condutos como alemães, de enviados da polícia a reuniões e de terem que pedir autorização policial para fazer reuniões. 
A diretoria da CIP preocupou-se após o rompimento do governo brasileiro com os países do Eixo em fevereiro de 1942, com a possibilidade de os judeus alemães serem considerados súditos do Eixo. Em agosto de 1942, os representantes da CIP manifestam veemente apoio ao governo brasileiro diante dos ataques nazistas e da declaração de guerra ao Eixo. A situação de guerra contra o Eixo e a disposição de mostrar patriotismo não foi suficiente, todavia, para a CIP concordar incondicionalmente com a campanha do Comitê Central de Socorro aos Israelitas Vítimas da Guerra, do Rio de Janeiro, em abril de 1942, para doar três aviões de treinamento para a Força Aérea Brasileira, a não ser que fosse eliminado do cabeçalho a referência como patrocinador da campanha ao Centro Hebreu-Brasileiro, e no lugar se colocasse "os Israelitas do Brasil". Vale dizer, o clima externo permitia que a CIP mantivesse firme sua oposição ao sionismo e à proposta de unificação institucional dos judeus, representado pelo Centro Hebreu-Brasileiro, recusando o sionismo e qualquer expressão unitária e política dos judeus paulistas.

Havia dificuldades para os imigrantes judeus alemães e austríacos no Rio de Janeiro, mas as informações a respeito não são objetivas. Um relatório da União, a Associação Beneficente Israelita, de dezembro de 1943, registra que forneceu ajuda aos "correligionários de países do Eixo que, embora de sentimentos reconhecidamente pró-aliados, tinham dificuldade na obtenção de licença de viagem e não podiam locomover-se, impedidos assim de ganhar a sua vida (representantes e viajantes profissionais). Para essa categoria, formularam-se centenas de apresentações e pedidos de concessão de salvo-condutos dirigidos à Delegacia de Estrangeiros, havendo muitas vezes necessidade de intervenção pessoal". Melhor dizendo, era possível realizar esforços pessoais para superar as restrições. Um exemplo, provavelmente entre muitos outros, das possibilidades de atuação no Brasil sem constrangimentos visíveis é a trajetória da psicóloga Betti Katzenstein (depois Schoenfeld), que imigrou em 1937 - depois que o Departamento de Psicologia na Universidade de Hamburgo foi fechado pelo nazismo - e passou a trabalhar em diversas instituições, como a Universidade de São Paulo, tendo inclusive publicado artigo nas revistas Archivos da Sociedade de Medicina Legal, em 1940, e Criminologia de São Paulo e Arquivos da Polícia Civil de São Paulo, em $1942^{28}$. Sua qualificação profissional foi suficiente para uma bem-sucedida inserção social e profissional, até em esferas de ação do Estado.

Embora possa haver memórias de constrangimento e restrições a indivíduos, não há, objetivamente, registro de que a principal entidade que congregava os judeus alemães tivesse sofrido interrupção em seu funcionamento, embora a comunidade judaico-alemã estivesse preocupada com a identificação de seus sócios como membros do Eixo. Não obstante, a CIP manteve nor- 
malmente suas atividades nos anos de guerra e exerceu livremente sua identidade judaico-alemã, inclusive os jovens do grupo escoteiro Avanhandava.

Em março de 1945, um editorial da revista semanal do Rio de Janeiro, Aonde Vamos?, mostrava uma postura altiva da comunidade judaica, cobrando posição do governo federal sobre imigração, sem qualquer constrangimento. O editorial diz inicialmente que "temos sustentado que o Brasil, sendo a mais completa democracia racial da atualidade, o único país civilizado da terra, onde não existe sombra de preconceito de sangue ou de cor e onde se realizou e ainda se realiza uma perfeita fusão de três raças", e em seguida afirma que "em nenhum país vivem os judeus em melhor comunhão com os naturais do que aqui. Inutilmente, procuraria alguém qualquer resquício de antisemitismo", para depois dizer que "a essa disposição de espírito da população não corresponde, todavia, a atitude das autoridades. Basta dizer que o Brasil é o único país do mundo em que os judeus alemães são colocados na mesma posição dos demais súditos do Reich"29.

De acordo com Alice Irene Hirschberg, filha do ativista, fundador da CIP e diretor do seu jornal, Alfred Hirschberg, e cujo livro tem sido considerado a história oficial da instituição: "As medidas tomadas pelo Brasil contra os atentados do nazi-fascismo à vida e propriedade brasileira, atingiram fortemente numerosos sócios da congregação, naturais da Alemanha e da Itália. Não foram tanto os fenômenos naturais e financeiros que perturbaram esse grupo de sócios, mas muito mais a sua situação psicológica e moral — isto é, o fato de que após terem sido atingidos primeiro e mais intensamente pelo nazi-fascismo na Alemanha e na Itália, depois, fora das fronteiras dos países que os haviam perseguidos, virem a ser equiparados aos seus perseguidores" ${ }^{30}$. Estas palavras podem ser tomadas como síntese: as medidas atingiram "fortemente" numerosos sócios da congregação, mas o maior impacto (sem desprezar o clima de intimidação geral e o confisco de bens como a poupança) foi "psicológico e moral". Refugiados profundamente identificados como alemães, testemunharam como a Alemanha e a Europa desmoronavam em meio a uma devastação terrível; imigrantes, viveram sempre sob a sombra de serem alemães durante a guerra no Brasil.

\section{CONCLUSÃO}

A história dos judeus no Brasil no período 1937-1945 tem sido olhada predominantemente pelo viés da ação do Estado, da ideologia e das leis antisemitas. Este artigo pretendeu mostrar como pode ser restrito, e mesmo equivocado, este olhar unilateral. As estratégias de identidade engendradas pelo grupo durante aquele período, o jogo entre nacionalidade e religião, entre ad- 
jetivo e substantivo, podem ser interpretados também por outro prisma, por mais difícil que seja determinar uma intencionalidade premeditada. É difícil diferenciar o que é uma estratégia do que é uma reação, afirmativa ou negativa; o que as pode diferenciar é a determinação.

A definição - a "invenção" — de uma identidade hebraico-brasileira ou hebreu-brasileira (e depois judaico-brasileira ou brasileiro-judaica), com o hífen e o elemento judaico relativamente secundário, foi constante no processo de implantação da "colônia israelita" em São Paulo a partir dos anos 1910. De um lado, esta identidade hifenizada era adequada a um projeto de inserção e de nacionalização da própria colônia israelita, que era brasileira e, hífen, algo mais. De outro, era adequada como resposta a uma sociedade que discutia intensamente, entre os anos 1920 e 1940, seu caráter nacional, homogeneidade étnica, projeto nacional, imigração e povoamento, sob um enquadre nacionalista e xenófobo. O que se chama de "questão nacional" passou a ser um tema onipresente nas discussões intelectuais e políticas do País desde os anos 1920, seja na tradição da direita seja na da esquerda. Pode-se sugerir que a problemática de definir o nome e achar o lugar do hífen é, do ponto de vista judaico, anterior ao Estado-Novo.

A importância que o tema do anti-semitismo na história do Brasil teve a partir do seu conhecimento público nos anos 1990 ganhou dois eixos fortes de registro: no campo dos historiadores, serviu como reforço às interpretações que aproximam o Estado Novo do fascismo e mesmo do nazismo. Do ponto de vista da memória da comunidade judaica, o registro do anti-semitismo serve à construção de uma identidade que enfatiza a vitimização e a perseguição em detrimento de valores de pertinência "positivos". Esta identidade judaico-brasileira, fundada em uma memória que sobrevaloriza o antisemitismo como central da inserção dos judeus no País, pode servir a uma questão mais complexa: com a ascensão social de camadas significativas da população judaica em cidades como São Paulo e Rio de Janeiro, os imigrantes e seus descendentes tiveram e têm que enfrentar a contradição de serem parte da elite brasileira (com seu racismo) e ao mesmo tempo parte de uma minoria que em muitos países sofre efetivamente com o preconceito e a perseguição. Assim, a centralidade do anti-semitismo na identidade judaico-brasileira pode organizar este impasse, remetendo a contradição para uma dimensão "passada" da origem, do início, de não-aceitação pela sociedade, mas que não tem ressonância afetiva na história e no presente de bem-sucedida inserção.

A memória e a história do anti-semitismo oferecem uma sedutora âncora de identidade, que dá às gerações uma identidade calcada na perseguição e no preconceito. Esta memória e esta história fortalecem determinadas identidades e inserções que preferem não olhar para o sucesso — em qualquer sen- 
tido - da moderna imigração judaica ao Brasil, da ascensão sem barreiras ao status de classes média e de elite e todos os seus valores, e instituem uma identidade judaico-hífen-brasileira, que idealiza o judaísmo supostamente autêntico pré-imigração, mas não realiza um projeto consistente de judaísmo no Novo Mundo, para não colocar em risco a bem sucedida integração social e cultural às camadas médias e altas do País.

Este artigo tentou mostrar que, longe da condição étnica e historiográfica de vítimas da história, os judeus no Brasil afirmaram várias estratégias para enfrentar o Estado-Novo, os anos da Segunda Guerra Mundial e o clima nacionalista intimidatório e xenófobo do regime de Getúlio Vargas, e o fizeram com destemor e efervescência institucional, social, econômica e cultural, em um momento de mobilidade social dos imigrantes. Esta outra história não pode ser apagada diante da história obscurantista do anti-semitismo, presente na política imigratória do Brasil e de círculos importantes de suas elites dirigentes, e das restrições à imigração de muitos refugiados do nazismo e da guerra. Esta outra história tampouco serve de atenuante ao regime instalado por Getúlio Vargas com o golpe do Estado-Novo em 1937. Os anos de 1937 a 1945 foram anos de mudança e de sedimentação de identidade de uma comunidade que deixa de se considerar imigrante e "estrangeira" para se afirmar judaico-brasileira, com questões ideológicas e práticas distintas.

\section{NOTAS}

Agradeço a Avraham Milgram e a Marcos Chor Maio pela leitura crítica e inúmeros comentários. A Jeffrey Lesser, além da leitura e críticas, agradeço por ter-me introduzido nesta área de pesquisa.

${ }^{1} \mathrm{O}$ primeiro autor a tratar deste tema e colocar o anti-semitismo como linha dominante da história dos judeus no Brasil durante o regime Vargas foi LEVINE, Robert, em seu informativo artigo "Brazil's Jews During the Vargas Era and After". In Luso-Brasilian Review, vol. V, n 1, June 1968, pp. 45-58. O livro mais significativo desta tendência, publicado vinte anos depois, é de CARNEIRO, Maria Luiza Tucci, cuja título tornou-se uma espécie de emblema deste período da história: O anti-semitismo na Era Vargas: fantasmas de uma geração. São Paulo: Brasiliense, 1988. Da mesma autora, Brasil, Um Refúgio nos Trópicos. A Trajetória dos Refugiados do Nazi-Fascismo. São Paulo: Estação Liberdade/Instituto Goethe, 1996. A autora trouxe uma consistente série de documentos anti-semitas do Itamaraty e das embaixadas e consulados do Brasil em vários países.

${ }^{2} \mathrm{Em}$ uma perspectiva inteiramente distinta, o livro mais importante sobre a moderna história dos judeus no Brasil, incluindo a questão da imigração e do anti-semitismo na década de 1930 e 1940, é LESSER, Jeffrey. O Brasil e a Questão Judaica. R.J., Imago, 1995. É interessante ler também LESSER, Jeffrey. Pawns of the Powerful. Jewish Imigration to Brazil, 1904-1945. Tese de Doutorado, Departament of History, New York University, 1989. O tra- 
balho de Lesser foi não apenas o primeiro estudo acadêmico sistemático sobre a história dos judeus no Brasil no século 20, a partir da imigração moderna, como também o primeiro a colocar a questão do anti-semitismo no contexto político, social e econômico do País. Vários artigos importantes nos anos 1990 trabalharam a questão do anti-semitismo nos anos 1930. Uma síntese muito bem feita da história da relação entre o Itamaraty e os judeus é de MILGRAM, Avraham. "O Itamaraty e os Judeus", texto inédito cedido pelo autor; do mesmo autor, "The Jews of Europe from the Perspective of the Brazilian Foreign Service, 1933-1941". In Holocaust and Genocide Studies, vol. 9, n 1, Spring 1995, pp. 94120. Uma síntese bibliográfica crítica sobre anti-semitismo no Brasil pode ser encontrada em CALAÇA, Carlos Eduardo e MAIO, Marcos Chor. "Cristãos Novos e Judeus: Um Balanço da Bibliografia sobre o Anti-Semitismo no Brasil”. BIB, Rio de Janeiro, $\mathrm{n}^{\circ} 49,1^{\circ}$ semestre de 2000, pp. 15-50. Para uma interessante crítica de Welcoming the Undiserables, ver MILGRAM, Avraham, Estudios Interdisciplinarios de America Latina y el Caribe (E.I.A.L.), Universidad Tel-Aviv, vol. 6 - nº 2, julio-deciembre 1995, pp. 145-149. Para Milgram, de 1937 em diante muitos judeus conseguiram entrar individualmente no País, graças a brechas e ações pessoais, mas foram barrados quando se tratava de grupos apoiados por organizações. Um interessante artigo sobre como se pode interpretar as referências anti-semitas no Brasil nos anos 1930 de forma diferente da convencional é de MAIO, Marcos Chor, "O Debate Racial no Brasil dos anos 30: o Caso dos Judeus na Visão de Gilberto Freyre”. In Judaica Latinoamericana. Estudios Histórico-Sociales, Jerusalem: Editorial Universitaria Magnes/Universidade Hebrea, 1997, pp. 143-161. "Sobre Igreja e anti-semitismo, ver BEN-DROR, Graciela. "The Catholic Elites in Brazil and Their Attitude Toward the Jews, 1933-1939”. In Yad Vashem XXX (Jerusalem 2002), pp. 229-270.

${ }^{3}$ LESSER, Jeffrey H. Negotiating National Identity: Immigrants and the Struggle for Ethnicity in Brazil. Durham: Duke University Press, 1998.

${ }^{4}$ Este artigo deve muito à abordagem e aos ensaios sobre etnicidade e identidade: de CUNHA, Manuela Carneiro da. Antropologia do Brasil. São Paulo: Brasiliense/Edusp, 1986. Sobre identidade judaica, a leitura de ALTER, Robert é sempre instigante; neste caso, os ensaios em Anjos Necessários. Tradição e Modernidade em Kafka, Benjamin e Scholem. Rio de Janeiro: Imago, 1993.

${ }^{5}$ Este episódio está muito bem documentado e analisado em MILGRAM, Avraham. Os judeus do Vaticano. A tentativa de salvação de católicos - não-arianos - da Alemanha ao Brasil através do Vaticano (1939-1942). São Paulo: Imago, 1994.

${ }^{6}$ Sobre a ideologia do Estado Novo: LENHARO, Alcir. Sacralização da Política. Campinas: Papirus, 1986; CAPELATO, Maria Helena. Os Arautos do Liberalismo: Imprensa Paulista 1920-1945. São Paulo: Brasiliense, 1988; PEDRO, Antonio. Samba da Legitimidade. São Paulo: 1980, dissertação de mestrado em História, FFLCH — USP; GOMES, Angela de Castro. A Invenção do Trabalhismo. $2^{\text {a }}$ ed., Rio de Janeiro: Relume Dumará, 1994; SCHWARTZMAN, Simon (org.). Estado Novo, um Auto-Retrato (Arquivo Gustavo Capanema). Brasília: Editora UnB, 1982 e GOMES, Angela de Castro (org.). Capanema: o ministro e seu ministério. Rio de Janeiro: FGV/Universidade São Francisco, 2000. O livro mais completo sobre o Integralismo é de TRINDADE, Hélgio. Integralismo, o fascismo brasileiro na década de 30. São Paulo: Difel, 1974. Sobre Gustavo Barroso e o anti-semitismo inte- 
gralista, ver MAIO, Marcos Chor. Nem Rotschild nem Trotsky: o pensamento anti-semita de Gustavo Barroso. Rio de Janeiro: Imago, 1992; RAGO FILHO, Antonio. A crítica romântica à miséria brasileira: o Integralismo de Gustavo Barroso. Dissertação de Mestrado, PUC-SP, 1989; e CYTRYNOWICZ, Roney. Integralismo e anti-semitismo nos textos de Gustavo Barroso na década de 30. Dissertação de Mestrado, FFLCH-USP, 1992. Sobre Integralismo, também cabe consultar HILTON, Stanley E. "Ação Integralista Brasileira: o Fascismo no Brasil, 1932-1938”, em: HILTON, Stanley e O Brasil e a Crise Internacional 1930/1945. Rio de Janeiro: Civilização Brasileira, 1977; e DEUTSCH, Sandra McGee. Las Derechas. The Extreme Right in Argentina, Brazil, and Chile 1890-1939. Stanford: Stanford Universtity Press, 1999. Em uma linha interpretativa que aproxima o Estado-Novo de um sistema totalitário, pode-se ler CANCELLI, Elizabeth. O mundo da violência: a polícia da era Vargas. Brasília: UnB, 1993. Em WIAZOVSKI, Taciana. Bolchevismo e Judaísmo: A comunidade judaica sob o olhar do Deops. São Paulo: Arquivo do Estado/Imprensa Oficial, 2001, em que há um levantamento da repressão policial a judeus identificados como comunistas nos anos 1930 a 1950.

${ }^{7}$ LEVINE. Op. cit., pp. 48 e 53; e MAIO, Marcos Chor. "Qual anti-semitismo? Relativizando a questão judaica no Brasil dos anos 30”. In Pandolfi, Dulce (org.). Repensando o Estado Novo, Rio de Janeiro: FGV, 1999, pp. 239 e 239. Para uma análise sociológica da comunidade judaica, ver o indispensável RATTNER, Henrique. Tradição e Ruptura (A comunidade judaica em São Paulo). São Paulo: Ática, 1977.

${ }^{8}$ Avraham Milgram destacou o significativo número de judeus que, sem qualquer apoio 420 institucional, conseguiu trazer parentes do exterior. Para ele, os judeus no Brasil tinham um importante grau de consciência sobre a política imigratória anti-judaica. Assim, o grande número de casos individuais é destacado tanto quanto a falta de ações institucionais. MILGRAM, Avraham. "Artur Hehl Neiva e a questão da imigração judaica ao Brasil”. In MILGRAM, Avraham et alli (org.). Em Nome da Fé. Estudos in memorian de Elias Lipiner. São Paulo: Perspectiva, 1999, pp. 145 a 156.

${ }^{9}$ Aonde Vamos?, Ano IV, 28 de outubro de 1943, p. 3.

${ }^{10}$ CYTRYNOWICZ, Roney. Guerra sem guerra. A mobilização e o cotidiano em São Paulo durante a Segunda Guerra Mundial. São Paulo: Edusp/Geração Editorial, 1999.

${ }^{11}$ Sobre a escola do Cambuci, a sinagoga da Lapa e o Asilo dos Velhos foram pesquisados três fundos do Arquivo Histórico Judaico Brasileiro (AHJB): Fundo Centro Israelita do Cambuci e Escola Religiosa Israelita-Brasileira do Cambuci; Fundo Sinagoga Israelita da Lapa; Relatório e resumo histórico apresentado e lido no primeiro aniversário do funcionamento do Asilo dos Velhos em $1^{\circ}$ de agosto de 1942" / Sociedade Religiosa Israelita Asilo dos Velhos - Fundo Alfred Hirschberg - Caixa 6/Acervo do AHJB. Sobre a história das entidades assistenciais, ver CYTRYNOWICZ, Roney. Unibes 85 anos. Uma história do trabalho assistencial na comunidade judaica em São Paulo. São Paulo: Narrativa Um, 2000.

${ }^{12}$ Anúncios e notícias em Aonde Vamos?, de 11-3-1943, pp. 9 e 16; 25-3-1943, pp. 7 e 13; 65-1943, p. 7; 30-3-1944, p. 9 e AV, 21-12-1944; sobre o movimento editorial, ver LIPINER, Elias. A Nova Imigração Judaica no Brasil. In Breve História dos Judeus no Brasil. Rio de Janeiro: Biblos, 1962; e sobre a Associação dos Israelitas Poloneses, ver Fundo Associação dos Israelitas Poloneses de São Paulo/Acervo AHJB. 
${ }^{13}$ Sobre o Colégio Talmud Torá, a documentação consultada foi: Documento da Diretoria Geral do Ensino/Delegacia Geral do Ensino Privado, 12-4-1935; Documento da Directoria do Ensino da Secretaria dos Negócios da Educação e Saude Pública, 6-5-1936; Licença para Funcionamento/Departamento Estadual de Imprensa e Propaganda (DEIP) de São Paulo, 12-11-1941; Estatutos da Sociedade Brasileira de Instrução Religiosa Israelita; Documento do Departamento de Educação de São Paulo/Registro de Professor Particular de Szejna Liwszyc, 13-4-1942. Todos estes documentos integram o Acervo Colégio Talmud Torá/AHJB.

${ }^{14}$ Sobre o Colégio Renascença foram utilizados: Atas de Reunião da Diretoria Executiva da Sociedade Hebraico-Brasileira Renascença (SHBR) dos dias 31-3-1941; 31-1-1944; 22-31944 e 3-8-1944; Ata da Assembléia Geral Extraordinária da SHBR de 2-7-1942 e 16-111942. Estes documentos estão no Acervo da SHBR.

${ }^{15}$ Sobre a Escola Luiz Fleitlich: Livro de Visitas da Escola Israelita Brasileira Luiz Fleitlich, de 27-7-1937 a 6-10-1969. Fundo Escola Luiz Fleitlich/Acervo AHJB.

${ }^{16}$ A legislação pode ser consultada em BOBBIO, Pedro Vicente (ed.). Lex. Coletânea de Legislação. Legislação Federal — 1938 São Paulo: Lex, 1938, Ano II, pp. 119 e 120. A frase entre aspas é de um relatório da diretora do Departamento Latino-Americano do escritório de Nova Iorque na Jewish Agency for Palestine (Col. J. Schneider, AHJB), citado por FALBEL, Nachman. Menashe: sua vida e seu tempo. São Paulo: Perspectiva, 1996; a carta de 68-1938, de Moshe Kostrinsky, secretário-geral do movimento Ichud Poalei Zion Zeire Zion, de Buenos Aires, citada por Falbel, pp. 69 e 70, encontra-se no Z4/10229, Central Zionist Archives, Jerusalém.

${ }^{17}$ MALAMUD, Samuel. Do Arquivo e da Memória. Fatos, personagens e reflexões sobre o sionismo brasileiro e mundial. Rio de Janeiro: Bloch, 1983, pp. 36 e 37.

${ }^{18}$ CZERESNIA, Fiszel, Uma História para Meus Netos. São Paulo: Perspectiva, 1998, p. 81.

${ }^{19}$ LESSER, Jeffrey. "From Antisemitism to Philosemitism: The Manipulation of Stereotypes in Brazil, 1935-1945". In Patterns of Prejudice, vol. 30, n 4, 1996, pp. 43-45. Em "Jewish Refugee Academics and the Brazilian State, 1935-1945”, em Ibero-Amerikanisches Archiv, 1-2:21 (1995), pp. 223-240. Lesser mostra a duplicidade brasileira nas atitudes ideológicas e práticas em relação aos acadêmicos judeus expulsos pelo nazismo, o que permitiu a entrada de cientistas. Outro artigo sobre o tema, na mesma publicação, é de SAIDEL, Rochelle G. e PLONSKY, Guilherme Ary. "How Scientists Fleeing Nazi Europe Contributed to Brazil's New Universities en 1933-1945” (pp. 169-190). Sobre a ascensão econômica dos mascates, ver LESSER, Jeffrey. "The Immigration and Integration of Polish Jews in Brazil, 1924-1934”. In The Americas, 51:2, October 1994, pp. 173-191.

${ }^{20}$ Aonde Vamos?, 30-11-1944, p. 16.

${ }^{21}$ TRENTO, Angelo. Do Outro Lado do Atlântico. Um século de imigração italiana no Brasil. São Paulo: Nobel/Istituto Italiano di Cultura di San Paolo / Institute Cultural Ítalo-Brasileiro, 1989, pp. 384 e 385.

${ }^{22}$ No caso dos imigrantes japoneses, ver LESSER, Jeffrey. Negotiating National Identity, op. cit.; em CYTRYNOWICZ, Roney. Guerra sem guerra, Op. cit., para quem houve uma campanha racista dirigida especificamente contra o grupo nipo-brasileiro durante o Estado 
Novo e este processo desestruturou profundamente o grupo nipo-brasileiro. Avraham Milgram já havia apontado que o tratamento que os judeus residentes no Brasil mereceram por parte do Estado Novo foi incomparavelmente melhor do que o tratamento às minorias alemã, italiana, japonesa e polonesa, in "O Itamaraty e os Judeus", p. 30. Sobre os alemães no Rio Grande do Sul, ver GERTZ, René. O Fascismo no Sul do Brasil. Porto Alegre, Mercado Aberto, 1987; do mesmo autor, O perigo alemão. Porto Alegre, Mercado Aberto, 1991. Alguns exemplos mais conhecidos de nacionalização do nome são os clubes de futebol como o Palestra Itália, que mudou seu nome para Palestra de São Paulo em março de 1942, e, logo em seguida, em setembro de 1942, para Sociedade Esportiva Palmeiras, conforme ARAÚJO, José Renato de Campos. Imigração e Futebol: O Caso Palestra Itália. São Paulo: Idesp/Fapesp, 2000.

${ }^{23}$ Atas de diretoria da Organização Feminina Israelita de Assistência Social (Ofidas), 12-11944 / 6-12-1944 e 27-2-1945 / Acervo União Brasileiro-Israelita do Bem-Estar Social (Unibes).

${ }^{24}$ Ata de reunião de diretoria da Sociedade Beneficente Israelita Linath Hatzedek (Policlínica), 5-1-1943 / Acervo AHJB.

${ }^{25}$ Estatutos da Sociedade Israelita de Beneficência Ezra. In: Goldberg, Eliza. O Serviço Social na Sociedade Israelita de Beneficência "Ezra" - Trabalho de conclusão de curso, apresentado para obtenção de título de Assistente Social, à Escola de Serviço Social da Pontifícia Universidade Católica de São Paulo, 1961.

$422{ }^{26}$ Livro de Atas de Assembléia Geral Ordinária e Assembléia Geral Extraordinária da Irmandade B’nai B’rith de São Paulo, de 1-3-1939 a 28-1-1942 / Acervo Pró-Memória da B’nai B'rith de São Paulo. O Livro de Atas é interrompido em 28-1-1942, com páginas em branco e não foi possível localizar o livro subseqüente, mas pode-se inferir que houve uma interrupção no registro formal das atas, conforme este primeiro livro. Em 28 de janeiro de 1942, última ata inscrita no Livro de Atas iniciado com a fundação da B'nei B'rith (e muitas páginas ainda disponíveis), quatro diretores pedem demissão de seus cargos, por não serem "brasileiros natos", e para preencher os cargos é convocada uma Assembléia Extraordinária, não se tendo mais registros até o final da guerra.

${ }^{27} \mathrm{~A}$ documentação consultada sobre a Sociedade Cemitério Israelita de São Paulo (SCISP) inclui as Atas de Diretoria de 1-2-1945 e 2-4-1945 / Acervo SCISP e WOLFF, Egon e Frieda. Breve Histórico da Sociedade Cemitério Israelita de São Paulo - 65 anos. Rio de Janeiro: Sociedade Cemitério Israelita de São Paulo, 1989, p. 26. Também foram consultadas as Atas de Assembléia Geral. Ata de Assembléia Geral Extraordinária de 18-1-1931/ Acervo SCISP. O primeiro pedido para a abertura do Cemitério Israelita da Vila Mariana, em São Paulo, data de 1915, justificado pela especificidade dos rituais funerários judaicos. Mas não era consenso aceitar a abertura de um cemitério particular e para um grupo religioso específico, como o israelita, diante da política oficial de separação entre Igreja e Estado com o advento da República em 1889. A autorização foi afinal concedida em 1919, quando começaram a ser realizados os primeiros enterros. Em 1923 deu-se a criação da Sociedade Cemitério Israelita de São Paulo. Agradeço à historiadora Paula Janovich por estas informações referentes à história dos cemitérios em São Paulo e sobre as discussões anteriores à criação da Sociedade Cemitério Israelita de São Paulo. 
${ }^{28} \mathrm{~A}$ documentação da Congregação Israelita Paulista pesquisada é a seguinte: Ata de reunião da Assembléia dos Representantes da CIP, 10-2-1942; Ata de reunião de diretoria de 23-5-1938; Ata da Assembléia dos Representantes da CIP, 6-9-1939 / 15-4-1942 e 25-81942; Carta de 16-3-1939 do presidente da Assembléia dos Representantes da Congregação Israelita Paulista - CIP aos seus membros/Acervo CIP; Carta de 16-3-1939 do presidente da Assembléia dos Representantes e da diretoria aos membros das duas instâncias; Ata de sessão da Assembléia dos Representantes da CIP, 27-1-1942, todos os documentos do Acervo da CIP. Sobre a psicóloga Betti Kazetnstein, os artigos são: "Alguns aspectos do psiquismo infantil". In Anais do $1{ }^{\circ}$ Congresso Paulista de Psicologia, Neurologia, Psiquiatria, Endocrinologia, Identificação, Medicina Legal e Criminologia (realizado de 24 a 30 de junho de 1938), 1941, e "Um teste coletivo do Jardim de Infância: meio de classificação e de estudo de caracteres psíquicos", in: Arquivos da Polícia Civil de São Paulo, vol. 4, 2º sem.1942, pp. 363-372. Agradeço estas informações à psicóloga Monica Musatti Cytrynowicz, que pesquisou a trajetória da psicóloga Betti Katzenstein para o Conselho Regional de Psicologia de São Paulo, no vídeo-documentário "Betti Katzenstein: uma psicóloga do século 20".

${ }^{29}$ Aonde Vamos?, 22-4-1943, p. 17; 29-4-1943, p. 17; 15-6-1944, p. 11 e 8-3-1945, p. 2.

${ }^{30}$ HIRSCHBERG, Alice Irene. Desafio e Resposta. A história da Congregação Israelita Paulista. São Paulo: Congregação Israelita Paulista, 1976, p. 73. 